\title{
SISTEM INFORMASI DESA DALAM MITIGASI BENCANA (PERAN DESA PENYANGGA DALAM IMPLEMENTASI SISTER VILLAGE)
}

\author{
Kanthi Pamungkas Sari ${ }^{1)}$, Priyo ${ }^{2)}$, Ahwy Oktradiksa ${ }^{3)}$ dan Agus Setiawan ${ }^{4)}$ \\ ${ }^{122) 334)}$ Universitas Muhammadiyah Magelang, Jl. Mayjend Bambang Soegeng Km 5 Metoyudan \\ Magelang \\ ${ }^{122) 34)}$ Email: kpamungkassari@ummgl.ac.id
}

\begin{abstract}
ABSTRAK
Tujuan kegiatan workshop adalah untuk : 1) meningkatkan pengetahuan masyarakat Deyangan tentang SID dalam mitigasi bencana sebagai Desa Penyangga; 2) rencana tindak lanjut menyusun struktur kelembagaan desa yang memiliki peran khusus dalam mitigasi bencana desa. Adapun mitra yang menjadi target kegiatan adalah Badan Perwakilan Desa (BPD) , Lembaga Pemberdayaan Pemuda (LPP) Desa Deyangan, Pembinaan Kesejahteraan Keluarga (PKK) Desa Deyangan. Mitra-mitra di atas merupakan organisasi sosial non struktural yang ada di desa, namun organisasi tersebut diharapkan mampu untuk menjadi agent of change bagi masyarakat Desa Deyangan secara umum. Metode kegiatan yang diselenggarakan meliputi : tahap persiapan, tahap pelaksanaan, tahap evaluasi dan rencana tindak lanjut. Hasil yang dicapai adalah : 1) Masyarakat memiliki peningkatan pengetahuan tentang sistem informasi desa baik yang terkait dengan dinamika informasi peringatan dini erupsi Gunung Merapi itu sendiri maupun arti pembaharuan informasi data-data kependudukan, pelayanan publik dan asset desa yang dilakukan secara berkala. Pengetahuan ini penting guna melaksanakan peran sebagai Desa Penyangga dari Desa Krinjing (KRB III) ; 2) Desa Deyangan telah memiliki lembaga khusus yang menangani mitigasi bencana yang bernama Lembaga Penanggulangan Bencana Desa Deyangan atau disingkat LPBDes. Struktur yang disepakati sudah terbentuk, untuk personil yang akan didudukkan dalam lembaga tersebut masih menunggu usulan dari dusun dan organisasi sosial yang ada di Desa Deyangan.
\end{abstract}

Kata kunci: Sistem Informasi Desa, Mitigasi Bencana, Sister Village

\section{PENDAHULUAN}

Posisi Gunung Merapi yang berada di Kabupaten Magelang memberikan konsekuensi munculnya bencana alam erupsi. Gunung Merapi termasuk gunung yang aktif di Indonesia. Aktiftas erupsi yang terjadi secara periodisasi telah ditetapkan rata-rata pada kisaran empat tahunan..

Kerugian akibat bencana erupsi Gunung Merapi sangatlah besar. Pada tahun 2010 akibat erupsi kerugian yang di tanggung oleh masyarakat Kabupaten Magelang tercatat mencapai Rp. 661.173.000.000,00 yang terdiri dari nilai kerusakan sebesar Rp. 316.767.000.000,00 serta nilai kerugian sebesar Rp. 344.416.000.000,00. Selain itu juga terdapat 52 orang meninggal dunia dan 98 mengalami luka atau sakit.

Pada saat terjadinya erupsi terdapat lebih dari 22.500 orang yang mengungsi di 152 titik baik itu di wilayah Kabupaten Magelang, wilayah Kota Magelang dan wilayah Kabupaten Temanggung. Fakta yang terjadi, begitu Gunung Merapi Erupsi para pengungsi menyebar, panik menuju ke wilayah-wilayah yang dinilai aman. Namun proses pengungsian masyarakat dari kawasan rawan bencana (KRB) tanpa adanya koordinasi atau petunjuk yang berarti dari pihak-pihak terkait. Masyarakat KRB mengungsi dengan bantuan sejumlah relawan namun setibanya mereka di wilayah terdekat 
yang dinilai aman yang diterima hanya sebagian saja atau mungkin ditolak karena desa tersebut sudah menerima pengungsi dari desa KRB. Bahkan ada yang merasa tidak siap menerima pengungsi yang jumlahnya banyak dan mereka mengungsi bersama binatang ternaknya. dan akibatnya pengungsi harus mencari lagi ketempat lain yang mau menerima meski kondisi yang demikian bisa menjadikan sebagian terpisah dengan keluarganya.

$$
\text { Berdasarkan Peraturan Bupati }
$$

Magelang Nomor 17 tahun 2011 tentang Fungsi Badan Penanggulangan Bencana Daerah (BPBD) Kabupaten Magelang. Pemerintah telah menetapkan upaya-upaya mitigasi bencana secara berencana bertahap dan berkesinambungan bersama pihak-pihak pemangku kepentingan. Salah satu upaya Pemerintah Daerah untuk mitigasi bencana tersebut adalah mengadakan program Desa Bersaudara (sister village) . Modal sosial yang akan dimiliki dalam pelaksanaan sister village adalah adanya kelompok dan jaringan, kepercayaan dan solidaritas, tindakan bersama dan kerjasama, informasi dan komunikasi, kohesi sosial dan inklusi, serta pemberdayaan dan tindakan politik. Program ini di cetuskan sejak tahun 2011 pasca erupsi Gunung Merapi. Ada 19 pasangan sister village yang telah ditetapkan dan mendapatkan pengakuan legalisasi dari Pemerintah Daerah Kabupaten Magelang. Jumlah tersebut disesuaikan dengan jumlah desa-desa di KRB
III Gunung Merapi. Desa KRB III merupakan desa yang paling besar resikonya apabila terjadi erupsi atau yang paling dekat dengan puncak Gunung Merapi. Selanjutnya masing-masing sister village akan menindak lanjuti dengan membuat "Kesepakatan Bersama" terutama menyangkut hal-hal teknis sesuai dengan kondisi obyektif masingmasing.

Satu diantara sister village yang terbentuk adalah antara Desa Krinjing Kecamatan Dukun dan Desa Deyangan Kecamatan Mertoyudan Kabupaten Magelang. Berdasarkan Surat Kesepakatan Bersama antara Pemerintahan Desa Deyangan dan Pemerintahan Desa Krinjing Nomor: 140/010/XI/2014 dan 140/001/XI/2014 tertanggal 10 Nopember 2014 telah ditetapkan sebagai Desa Bersaudara (sister village). Dalam penetapan tersebut kesepakatan dibuat bertujuan untuk pengurangan resiko atau mitigasi bencana erupsi Gunung Merapi. Selanjutnya diharapkan bahwa dengan sister village ini penanganan pengungsi dari Desa Krinjing sebagai KRB III ke Desa Deyangan sebagai Desa Penyangga akan menjadi lebih terencana, terkoordinir dan terpadu sehingga akan meminimalisir kerugian maupun korban akibat bencana yang terjadi.

Sejak di tetapkan sebagai Desa Penyangga, masyarakat Desa Deyangan belum pernah mendapatkan sosialisasi atau pelatihan tentang sistem informasi desa baik 
yang terkait dengan dinamika informasi peringatan dini dari erupsi Gunung Merapi itu sendiri maupun informasi kependudukan Desa Krinjing yang akan menjadi tamu di wilayahnya. Selain itu juga diperlukan pengetahuan akan sistem komunikasi yang berbasis komunitas sebagai Desa Penyangga. Konsentrasi dari para pemangku kepentingan kebencanaan di daerah masih ada pada desadesa di KRB III. Konsentrasi tersebut tidak salah karena hal itu sebagai upaya preventif agar masyarakat dapat merespon informasi tersebut dengan cepat dan tepat. Kesigapan dan kecepatan reaksi masyarakat diperlukan karena waktu yang sempit dari saat dikeluarkannya informasi dengan saat (dugaan) datangnya bencana. Kondisi kritis, waktu sempit, bencana besar dan penyelamatan penduduk merupakan faktorfaktor yang membutuhkan peringatan dini. Namun sebagai Desa Penyangga juga perlu dipersiapkan untuk bisa menerima pengungsi sebagai "saudaranya" datang dan mampu memperlakukan secara layak bagi kemanusiaan. Untuk itu masyarakat Desa Deyangan memerlukan kegiatan Workshop tentang Sistem Informasi Dini (SID) dalam Mitigasi Bencana sebagai Desa Penyangga.

Tujuan kegiatan workshop adalah untuk : 1) meningkatkan pengetahuan masyarakat Deyangan tentang SID dalam mitigasi bencana sebagai Desa Penyangga; 2) rencana tindak lanjut menyusun struktur kelembagaan desa yang memiliki peran khusus dalam mitigasi bencana desa. Adapun mitra yang menjadi target kegiatan adalah Badan Perwakilan Desa (BPD) , Lembaga Pemberdayaan Pemuda (LPP) Desa Deyangan, Pembinaan Kesejahteraan Keluarga (PKK) Desa Deyangan. Mitra-mitra di atas merupakan organisasi sosial non struktural yang ada di desa, namun organisasi tersebut diharapkan mampu untuk menjadi agent of change bagi masyarakat Desa Deyangan secara umum.

\section{MASALAH}

Sejak di keluarkan Surat Kesepakatan Bersama antara Pemerintahan Desa Deyangan dan Pemerintahan Desa Krinjing Nomor: 140/010/XI/2014 dan 140/001/XI/2014 tertanggal 10 Nopember 2014 Desa Deyangan telah bersedia sebagai Desa Penyangga pengungsi dari Masyarakat Desa Krinjing Kecamatan Dukun Kabupaten Magelang. Saat ini jumlah penduduk Desa Krinjing sebanyak 1.140 orang (Kecamatan Dukun dalam Angka, 2017). Jadi apabila erupsi Gunung Merapi sudah pada level "tanggap darurat" maka masyarakat Desa Deyangan harus siap untuk menerima pengungsi dengan jumlah dan kondisi obyektif yang ada. Namun sejak ditetapkannya sebagai Desa Penyangga masyarakat Desa Deyangan belum banyak yang mendapatkan pengetahuan tentang sistem informasi dini baik yang terkait dengan dinamika informasi peringatan dini dari 
erupsi Gunung Merapi maupun informasi kependudukan Desa Krinjing. BPBD Kabupaten Magelang sudah pernah melakukan sosialisasi tentang hal itu namun hanya terbatas pada perwakilan dari perangkat Desa.

\section{METODOLOGI}

Adapun tahap-tahap metodologi kegiatan pengabdian kepada masyarakat adalah:

1. Tahap Persiapan

Kegiatan diawali dengan koordinasi dengan beberapa pihak. Koordinasi internal dilakukan oleh Tim PPDM berkaitan dengan persiapan instrumen yang akan dikembangkan, peralatan workshop dan time schedule kegiatan. Sedangkan koordinasi eksternal dilaksanakan bersama Bappeda, BPBD, Mubammadiyah Disaster Management Center (MDMC) Kabupaten Magelang dan Pemerintah Desa Deyangan Kabupaten Magelang. Sambil mengurus perizinan kegiatan sesuai dengan prosedur yang berlaku di wilayah Kabupaten Magelang.

2. Tahap Pelaksanaan

Pada tahap pelaksanaan terdapat 2 kegiatan pokok, yaitu: sosialisasi tentang early warning system (EWS) dan pengembangan sistem informasi, komunikasi desa berbasis masyarakat sebagai Desa Penyangga,

3. Tahap Evaluasi dan Rencana Tindak Lanjut
Evaluasi dilaksanakan dengan meminta tanggapan dari peserta mengenai kesesuaian kebutuhan tentang materi sosialisasi, penyampaian narasumber, manfaat kegiatan, dan saran serta perbaikan. Selanjutnya dilakukan rencana tindak lanjut yang berorientasi pada revitalisasi struktur kelembagaan desa yang disepakati sebagai organisasi yang akan menangani masalah manajemen mitigasi bencana desa.

\section{PEMBAHASAN}

Kegiatan pengabdian kepada masyarakat ini merupakan bagian dari Program Pengembangan Desa Mitra (PPDM) yang rencananya akan dilaksanakan selama 3 (tiga) tahun secara berturut-turut (20182020). Pada tahun pertama (2018) kegiatan difokuskan pada sosialisasi dan pembentukan struktur yang jelas dan terarah pada upaya menuju Desa Penyangga. Tahun kedua (2019) difokuskan pada upaya pemberdayaan organisasi yang didukung dengan supporting team yang potensial dan terlatih. Tahun ketiga (2020) kegiatan difokuskan pada pengembangan ketrampilan dari seluruh pemangku kepentingan secara terintegrasi untuk mewujudkan Deyangan sebagai Desa Penyangga Tangguh.

Kegiatan dilaksanakan selama dua hari yaitu pada tanggal 12 dan 13 April 2018 di Pendopo Kantor Kepala Desa Deyangan Mertoyudan Kabupaten Magelang. Diikuti oleh 54 orang yang terdiri dari perwakilan 
BPD, perangkat desa, kader posyandu, perwakilan dari organisasi Lembaga Pemberdayaan Pemuda dan perwakilan dari 11 Dusun yang ada di wilayah Desa Deyangan. Guna pencapaian tujuan kegiatan sebagaimana yang diharapkan tim bekerjasama dengan Pemerintah Daerah Kabupaten Magelang dalam hal ini melalui BPBD dan MDMC.

\section{SISTEM INFORMASI DESA}

Sebagai upaya untuk mitigasi bencana erupsi Gunung Merapi Pemerintah Kabupaten Magelang mulai tahun 2011 sampai dengan 2014 membentuk 19 sister village. Sister village adalah persaudaraan dua desa ataupun lebih, antara desa yang mempunyai ancaman tingkat tinggi bencana Gunung Merapi (KRB III) dengan desa yang yang dinilai aman dari ancaman erupsi Gunung Merapi (Penyangga). Masyarakat dapat tetap merasa tenang meski hidup berdampingan dengan ancaman bencana karena implementasi sister village akan memberikan kepastian tempat tujuan pengungsian; mengurangi kepanikan dan kesemrawutan proses pengungsian; memudahkan pelayanan pengungsi dengan landasan persaudaraan.

Implementasi kegiatan tersebut tidak cukup hanya dengan semangat dan kesepakatan saja, namun lebih jauh dibutuhkan daya dukung lainnya diantaranya adalah sistem informasi dan komunikasi antar kedua desa harus terjalin dengan baik. Salah satu diantaranya adalah membangun sistem informasi desa (SID) tentang data-data kependudukan, pelayanan publik dan asset desa guna mengurangi ketidakjelasan informasi atas data-data tersebut. Apabila terdapat ketidakjelasan atas data-data kependudukan, pelayanan publik dan asset desa maka hal itu menimbulkan potensi social disorder bahkan dapat menimbulkan konflik sosial. Saat ini Pemerintah Kabupaten Magelang sudah membangun dan mengembangkan SID yang digunakan untuk mengelola data kependudukan, pelayanan publik, data sumber daya dan asset desa maupun informasi lain tentang desa serta promosi potensi desa. Mekanismenya adalah sebagai berikut :

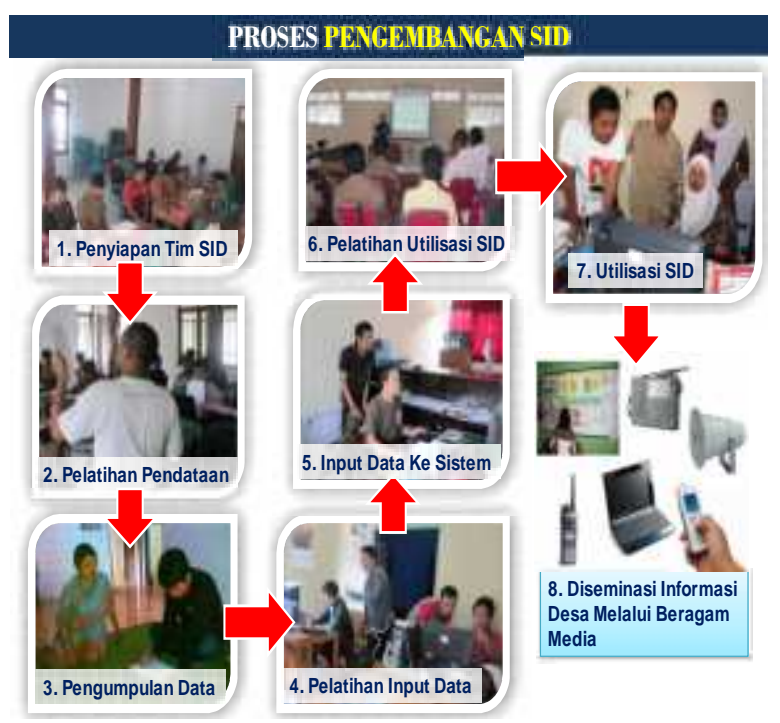

Gambar 1. Proses Pengembangan SID 
Data-data kependudukan, pelayanan publik, dan asset desa yang diinputkan dan terupdate secara periodik akan sangat bermanfaat untuk mengetahui kondisi obyektif dengan berbasis teknologi internet. Siapapun yang terhubung dengan jaringan SID maka akan dapat mengetahui data-data tersebut dengan mudah. Sehingga apabila terjadi erupsi Merapi data-data masyarakat KRB III akan tidak akan hilang dan dokumennya teridentifikasi dengan baik.

Dengan menggunakan SID yang senantiasa diperbaharui secara berkala maka akan menjadi informasi yang sangat penting terutama bagi Desa Penyangga karena berhubungan dengan jumlah calon pengungsi yang akan datang dari Desa KRB III. Sehingga kebutuhan sarana dan prasarana pendukung sebisa mungkin dapat dipersiapkan, disesuaikan dengan kemampuan dan kebutuhan. Mulai dari tempat penampungan pengungsi, kebutuhan MCK, kebutuhan konsumsi. Sampai pada tempat penampungan sementara binatang ternak yang akan dibawa jika terancam keselamatannya. Selain itu jika teridentifikasi ada anggota masyarakat yang memiliki kondisi khusus misalnya cacat, orangtua renta, wanita hamil, sakit berat ataupun kondisi khusus lainnya maka perlu dipersiapkan layanan yang tepat dan layak untuk mereka.

Sistem informasi peringatan dini (early warning system/EWS) merupakan serangkaian sistem yang berfungsi untuk memberitahukan akan terjadinya kejadian alam. Dinamika perubahan kondisi yang diinformasikan sebagai peringatan dini dari erupsi Gunung Merapi akan sangat dibutuhkan oleh desa-desa yang telah ditetapkan sebagai sister village. Pengetahuan tentang EWS bagi Desa KRB III akan dimanfaatkan untuk melakukan persiapan yang tepat kapan saatnya mengungsi agar resiko akibat bencana dapat diminimalisir. Bagi Desa Penyangga pengetahuan tersebut bermanfaat untuk melakukan persiapan untuk menerima pengungsi dari Desa KRB III, karena menerima pengungsi dalam jumlah yang banyak dibutuhkan ketangguhan baik moril maupun materiil.

\section{RENCANA TINDAK LANJUT}

Selain sistem informasi desa yang harus diketahui dan dipahami oleh masyarakat Desa Penyangga, hal lain yang harus dilakukan adalah sebagai berikut:

a) Memiliki organisasi atau lembaga desa yang menangani khusus kebencanaan, (misalnya: Organisasi Pengurangan Resiko Bencana, Lembaga Penanggulangan Bencana Desa

b) Membangun relasi yang baik dengan desa/ kawasan rawan bencana III 
agar terbentuk chemistry antara keduanya

c) Memiliki MOU atau kesepakatan (antara desa pengungsi dan desa penyangga) berkaitan penetapan sebagai sister village, hak dan kewajiban serta kegiatan-kegiatan yang diupayakan baik sebagai masing-masing desa maupun secara bersama-sama

d) Mempunyai fasilitas-fasilitas pengungsian yang layak bagi kemanusiaan atau hampir sama dengan desa KRB III.

e) Memiliki panduan atau SOP tentang cara-cara menjadi Desa Penyangga termasuk di dalamnya bagaimana cara-cara menerima pengungsi

f) Membentuk supporting team untuk membantu pengungsi dalam mengatasi trauma healing, psikososial, pola hidup bersih dan sehat

g) Sosialisasi kepada masyarakat secara keseluruhan dan melakukan simulasi bersama

Saat ditetapkannya sebagai sister village dengan Desa Krinjing Kecamatan Dukun, Desa Deyangan belum memiliki organisasi atau lembaga desa yang berfungsi untuk menangani khusus kebencanaan (misalnya: Organisasi Pengurangan Resiko Bencana, Lembaga Penanggulangan Bencana Desa).
Organisasi ini menjadi penting, karena yang akan menjadi penggerak dalam melaksanakan peran sebagai Desa Penyangga. Oleh karena itu pada saat kegiatan workshop ini peserta bermaksud untuk menyepakati nama dan struktur kelembagaannya. Nama lembaganya adalah Lembaga Penanggulangan Bencana Desa Deyangan disingkat LPBDes Deyangan. Struktur tersebut adalah sebagai berikut:

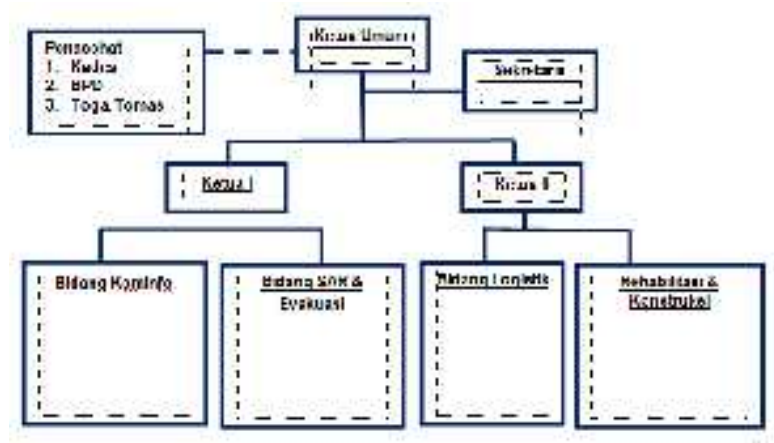

Gambar 2. Struktur Kelembagaan 


\section{KESIMPULAN}

1) Masyarakat memiliki peningkatan pengetahuan tentang sistem informasi desa baik yang terkait dengan dinamika informasi peringatan dini erupsi Gunung Merapi itu sendiri maupun arti pembaharuan informasi data-data kependudukan, pelayanan publik dan asset desa yang dilakukan secara berkala. Pengetahuan ini penting guna melaksanakan peran sebagai Desa Penyangga dari Desa Krinjing (KRB III)

2) Desa Deyangan telah memiliki lembaga khusus yang menangani mitigasi bencana yang bernama Lembaga Penanggulangan Bencana Desa Deyangan atau disingkat LPBDes. Struktur yang disepakati sudah terbentuk, untuk personil yang akan didudukkan dalam lembaga tersebut masih menunggu usulan dari dusun dan organisasi sosial yang ada di Desa Deyangan.

\section{UCAPAN TERIMA KASIH}

Terima kasih kepada Direktorat Riset dan Pengabdian Masyarakat Kementrian Riset dan Teknologi Pendidikan Tinggi (DRPM Ristekdikti) telah mendani kegiatan PPDM tahun 2018. Terima kasih pula kami sampaikan kepada LP3M; Pemerintah Daerah Kabupaten Magelang melalui BPBD dan MDMC yang telah bersinergi dan memberikan dukungan moril maupun materiil sehingga kegiatan dapat berjalan dengan lancar dan bermanfaat bagi mitra kegiatan

\section{DAFTAR PUSTAKA}

BPS Kabupaten Magelang, 2016. Kabupaten Magelang dalam Angka. Pemerintah Daerah Kabupaten Magelang

Burhan, 2002. Teknik Pemberdayaan Masyarakat Secara Partisipatif. Departemen Agribisnis FEM IPB.

\section{Renstra SKPD BPBD Kabupaten Magelang} tahun 2014-2019

Peraturan Bupati Magelang Nomor : 41 tahun 2011

BPS Kabupaten Magelang, 2017. Kecamatan Dukun dalam Angka Pemerintah Daerah Kabupaten Magelang 